\title{
Penerapan Strategi Hembusan Angin Kencang untuk Meningkatkan Motivasi Belajar Siswa pada Mata Pelajaran Ilmu Pengetahuan Sosial Kelas V Sekolah Dasar Negeri 20 Pekanbaru
}

\author{
Windy Anggraini ${ }^{1}$, Nurhasanah Bakhtiar ${ }^{2}$ \\ 1,2Program Magister Pendidikan Guru Madrasab Ibtidaiyah, Universitas Islam Negeri Sultan Syarif Kasim Riau \\ e-mail: anggrainiw045@gmail.com
}

\begin{abstract}
$\boldsymbol{A B S T R A C T}$. This research aimed at knowing the enhancement of student learning motivation on Social Science subject at the fifth grade of State Elementary School 20 Pekanbaru. This research was instigated by the low of student learning motivation seen on the ongoing learning process that students did not pay attention to the teacher explanation and not want to question.

This research was a Classroom Action Research. The subjects of this research were teachers and the fifth grade students, and the object was Hembusan Angin Kencang strategy in increasing student learning motivation on Social Science subject. This research was conducted for two circles, every circle comprised two meetings. Observation, and documentation were the techniques of collecting the data. The data of teacher and student activity, and student learning motivation were analyzed by using the Percentage formula as follows: $P=f / N \times 100 \%$.

Based on the data analysis, Hembusan Angin Kencang strategy could increase student learning motivation. It could be identified that student learning motivation was $61 \%$ before treatment. After treating in the first circle, student leaning motivation was $70 \%$. Whereas in the second circle, student learning motivation increased to $82.75 \%$. Thus, it could be concluded that the implementation of Hembusan Angin Kencang strategy could increase student learning motivationon Social Science Subject at the Fifth Grade of State Elementary School 20 Pekanbaru.
\end{abstract}

Keywords: Strategy, Hembusan Angin Kencang, Student Learning Motivation.

\section{PENDAHULUAN}

Mengajar pada dasarnya merupakan suatu usaha untuk menciptakan kondisi atau sistem lingkungan yang mendukung dan memungkinkan untuk berlangsungnya proses belajar. Mengajar adalah menyampaikan pengetahuan pada siswa. Jadi, guru yang memegang posisi kunci dan mengendalikan seluruh kegiatan proses belajar mengajar di kelas. Di dalam pembelajaran di kelas guru Sekolah Dasar mengajarkan banyak disiplin ilmu, di antaranya ilmu tentang fenomena sosial, ilmu tentang bahasa, ilmu tentang fenomena alam dan sebagainya. Salah satu mata pelajaran yang mempelajari tentang fenomena sosial adalah Ilmu Pengetahuan Sosial ( IPS). Ilmu pengetahuan sosial merupakan bagian dari ilmu pengetahuan yang diakui bahwa ide ilmu pengetahuan sosial berasal dari literatur pendidikan Amerika Serikat. Nama asli ilmu pengetahuan sosial di Amerika Serikat adalah Social Studies. Istilah tersebut pertama kali pertama kali dipergunakan sebagai nama sebuah komite yaitu Committee of Social Studies yang didirikan 
pada tahun 1993. Tujuan dari lembaga tersebut adalah sebagai wadah himpunan tenaga ahli yang berminat pada kurikulum-kurikulum ilmu sosial di tingkat sekolah dan ahli-ahli ilmu-ilmu sosial di tingkat sekolah dan ahli ilmu-ilmu sosial yang mempunyai minat yang sama (Achmad Sanusi, 2007).

Ilmu Pengetahuan Sosial merupakan salah satu mata pelajaran yang mengkaji seperangkat peristiwa, fakta, konsep, dan generalisasi yang berkaitan dengan ilmu sosial. Melalui mata pelajaran ilmu pengetahuan sosial, siswa diarahkan untuk dapat menjadi warga negara Indonesia yang demokratis, dan bertanggung jawab, serta warga dunia yang cinta damai (Wahid Murni, 2010). Ilmu pengetahuan sosial dalam kategori keilmuannya adalah ilmu yang diperoleh dari fenomena-fenomena sosial yang ada di sekitar. Ilmu pengetahuan sosial dalam dunia pendidikan menjadi sebuah cabang ilmu yang terdiri dari beberapa cabang ilmu-ilmu sosial yang berdiri dan berkembang sesuai konsep dasar masing-masing (Sukma Erni, 2011). Ilmu pengetahuan sosial merupakan hasil kombinasi atau hasil pemfusian atau perpaduan dari sejumlah mata pelajaran seperti geografi, ekonomi, sejarah, sosiologi, antropologi, politik (Saidiharjo dan Sumadi, 2011).

Tinggi atau rendahnya tingkat pemahaman siswa terhadap suatu materi pelajaran dapat dilihat dari keinginan atau motivasi belajarnya. Berhasilnya suatu pembelajaran salah satunya ditentukan oleh motivasi belajar atau dorongan belajar siswa terhadap suatu pelajaran. Dalam proses belajar motivasi sangat diperlukan, sebab seseorang yang tidak mempunyai motivasi belajar tidak mungkin melakukan aktivitas belajar (Syaiful Bahri Djamarah, 2011).

Fenomena yang terlihat di sekolah dasar bahwasannya mata pelajaran ilmu pengetahuan sosial merupakan mata pelajaran yang dianggap membosankan bagi siswasiswi di Sekolah Dasar. Secara rinci gejala-gejala yang menunjukkan rendahnya motivasi siswa saat belajar ilmu pengetahuan sosial antara lain : 1. Saat belajar di kelas sebagian siswa sibuk sendiri dan kurang memperhatikan guru saat menjelaskan pelajaran ilmu pengetahuan sosial, 2. Saat diberikan soal sebagian siswa tidak termotivasi untuk menyelesaikan soal yang diberikan guru, 3. Siswa menganggap bahwa pelajaran ilmu pengetahuan sosial adalah mata pelajaran yang kurang menarik dan membosankan. Gambaran dari gejala-gejala di atas dapat disimpulkan sementara bahwa motivasi belajar siswa belum optimal, khususnya pada mata pelajaran ilmu pengetahuan sosial. Hal tersebut juga berarti kurangnya motivasi belajar siswa dalam pelaksanaan pembelajaran. Hal ini berkemungkinan dipengaruhi oleh cara guru yang kurang menarik dan kurang melibatkan siswa dalam pelaksanaan pembelajaran dengan penggunaan strategi yang tepat. Maka dari itu perlu adanya pemilihan strategi yang tepat bagi seorang guru untuk melakukan kegiatan pembelajaran demi tercapainya tujuan yang ingin dicapai.

Berdasarkan penelitian sebelumnya, penelitian yang dilakukan oleh Octavia Kurniawati 2012 yang berjudul "Penerapan Strategi The Great Wind Blows untuk Meningkatkan Hasil Belajar pada Mata Pelajaran PKN Siswa Kelas IV SDN III Kopen Kecamatan Jatipurno Kabupaten Wonogiri (Octavia Kurniawati, 2011). Hasil penelitian yang dilaksanakan oleh Octavia Kurniawati adalah adanya peningkatan hasil belajar siswa dari hasil pembelajaran pada Siklus I 70,9\% yang tuntas belajar dan hasil belajar meningkat menjadi 91,7\% pada siklus ke II. Dengan demikian dapat disimpulkan bahwa penerapan strategi the great wind blows dapat meningkatkan hasil belajar pada mata pelajaran PKN Siswa Kelas IV SDN III Kopen Kecamatan Jatipurno Kabupaten Wonogiri. Persamaan dengan penelitian yang penulis lakukan adalah sama-sama menggunakan 
strategi hembusan angin kencang. Namun, memiliki perbedaan yaitu penelitian yang dilakukan Octavia Kurniawati pada kelas IV SDN untuk meningkatkan hasil belajar pada mata pelajaran PKN. Sedangkan yang penulis lakukan pada kelas V untuk meningkatkan motivasi belajar pada mata pelajaran IPS.

Mengingat pentingnya motivasi belajar siswa pada mata pelajaran ilmu pengetahuan sosial, maka guru perlu berupaya meningkatkan kualitas pembelajaran dengan melakukan beberapa usaha perbaikan dalam proses pembelajaran. Salah satu usaha yang dapat dilakukan adalah menerapkan strategi pembelajaran yang tepat yang membuat siswa memiliki motivasi untuk belajar. Seorang guru memerlukan kreativitas untuk menumbuh kembangkan daya imajinasi dan berfikir bagi peserta didiknya. Oleh karena itu, diperlukan upaya guru untuk menciptakan suasana pembelajaran yang aktif, kreatif, dan menyenangkan dengan menerapkan strategi pembelajaran yang tepat. Gurulah yang merupakan kunci utama keberhasilan maupun kegagalan seorang anak (Mardia Hayati, Nurhasnawati, 2014). Strategi Hembusan Angin Kencang merupakan kegiatan pembuka yang cepat dan memberi siswa keleluasaan untuk bergerak dan tertawa, serta dapat memecahkan kebekuan yang terjadi pada siswa selama proses pembelajaran. Kegiatan ini merupakan sarana pembentuk tim yang baik dan menjadikan siswa untuk lebih mengenal satu sama lain (Melvin Siberman, 2009). Berdasarkan penjelasan di atas, diperkirakan strategi ini cukup variatif dan bisa digunakan dalam pembelajaran IPS. Oleh karena itu, peneliti tertarik ingin melakukan suatu penelitian tindakan sebagai upaya dalam melakukan perbaikan terhadap pembelajaran.

\section{METODOLOGI}

Penelitian ini termasuk dalam penelitian tindakan kelas dan berlangsung selama dua siklus, yang meliputi beberapa tahapan, yaitu: perencanaan, tindakan, observasi, dan refleksi serta terbagi dalam dua siklus selama 6 bulan. Penelitian berlangsung di kelas V Sekolah Dasar Negeri 20 Pekanbaru pelajaran 2016-2017 dengan jumlah siswa sebanyak 38 orang.

Data dikumpulkan melalui tiga cara, yakni: (1) observasi, (2) wawancara, dan (3) dokumentasi. Lembar observasi digunakan untuk mengamati aktivitas siswa dan guru, dan motivasi belajar siswa. Pengamatan difokuskan pada aktivitas siswa selama mengikuti proses pembelajaran. Pengamatan juga dilakukan untuk mengetahui keterlaksanaan proses pembelajaran dimaksudkan untuk mengetahui adanya kesesuaian antara perencanaan tindakan dan pelaksanaan tindakan.

Observasi dilakukan untuk melihat proses pembelajaran yang dilaksanakan guru dan siswa dengan penerapan strategi pembelajaran hembusan angin kencang. Observasi dilakukan oleh teman sejawat yang bertugas sebagai pengamat. Data penelitian dianalisis secara kuantitatif dan kualitatif. Analisis kuantitatif menggunakan tabel frekuensi dan persentase $81-100 \%$ dengan kategori sangat baik, 71-80\% dengan kategori baik, 61-70\% dengan kategori cukup baik, 41-60\% dengan kategori kurang baik.

\section{HASIL DAN PEMBAHASAN}

\section{Hasil Penelitian}

Strategi hembusan angin kencang merupakan kegiatan pembuka yang cepat dan memberi siswa keleluasaan untuk bergerak dan tertawa, serta dapat memecahkan kebekuan 
yang terjadi pada siswa selama proses pembelajaran. Kegiatan ini merupakan sarana pembentuk tim yang baik dan menjadikan siswa untuk lebih mengenal satu sama lain (Melvin Siberman, 2009). Langkah-langkah strategi hembusan angin kencang adalah sebagai berikut: 1) Aturlah kursi secara melingkar. Perintahkan siswa untuk duduk pada salah satu kursi. Harus ada cukup kursi bagi semua siswa. 2) Katakan bahwa jika mereka setuju dengan pernyataan Anda berikutnya, mereka harus berdiri dan berpindah ke kursi lain. 3) Berdirilah di tengah lingkaran dan katakan : Nama Saya adalah ........... dan Angin Kencang Berhembus bagi semua orang yang .... pilihlah ending yang pas, misalnya yang menyukai es krim coklat 4) Sampai di sini, setiap siswa yang menyukai es krim coklat itu berdiri dan berpindah, pastikan bahwa Anda menempati salah satu kursi kosong Jika sudah, selanjutnya satu orang siswa tidak akan mendapatkan kursi untuk duduk dan akan menggantikan Anda sebagai orang yang berdiri di tengah-tengah. 5) Perintahkan agar siswa yang baru berdiri di tengah-tengah itu menyelesaikan kalimat yang tidak utuh sejenis, misalnya: Nama saya adalah ............. dan Angin Kencang Berhembus untuk semua orang yang........ dengan menambahkan ending baru. Ending ini bisa bernada canda (misalnya, yang tidur dengan keremangan malam) atau yang serius (misalnya, yang khawatir dengan defisit anggaran pemerintah pusat). 6) Mainkan permainan ini dengan mempertimbangkan kesesuaian situasi. Kelebihan strategi hembusan angin kencang: 1) dapat meningkatkan kretifitas siswa dalam belajar 2) melatih siswa menjadi berani dihadapan teman-teman sekelasnya 3) melatih siswa dalam menjawab pertanyaan dengan cepat (Meidi Rizki, 2015). Kekurangan strategi hembusan angin kencang: 1) membuat pengetahuan siswa tidak menjadi luas, hanya sebatas pengetahuan sekitar mereka 2) guru sulit mengontrol kelas (Ariani Rosida, 2014)

Istilah motivasi berasal dari kata motif yang dapat diartikan sebagai kekuatan yang terdapat dalam diri individu yang menyebabkan individu tersebut bertindak atau berbuat. Motif tidak dapat diamati secara langsung tetapi dapat diinterpretasikan dalam tingkah lakunya, berupa rangsangan, dorongan, atau pembangkit tenaga munculnya suatu tingkah laku tertentu. Motivasi belajar merupakan kekuatan, daya dorong, atau alat pembangun kesediaan dan keinginan yang kuat dalam diri peserta didik untuk belajar secara aktif, kreatif, efektif, inovatif, dan menyenangkan dalam rangka perubahan perilaku, baik dalam aspek kognitif, afektif, dan psikomotor (Nanang Hanafiah, 2009). Dapat dipahami bahwa motivasi sangat dibutuhkan dalam belajar agar dapat meningkatkan hasil belajar yang baik terhadap materi yang dihadapinya dalam kegiatan pembelajaran. Motivasi erat sekali kaitannya dengan keinginan dan ambisi. Bila salah satunya tidak ada, maka motivasi tidak akan timbul. Banyak dikalangan manusia yang mempunyai keinginan dan ambisi besar, tetapi kurang mempunyai inisiatif dan kemampuan untuk mengambil langkah untuk mencapainya, sehingga keinginan dan ambisi tersebut menjadi sia-sia. Hal ini menujukkan bahwa kurangnya energi pendorong dari dalam diri manusia itu sendiri atau kurangnya motivasi. Motivasi yang ada pada diri setiap orang itu memiliki ciri-ciri sebagai berikut: 1) tekun menghadapi tugas, 2) ulet menghadapi kesulitan, 3) menunjukkan minat terhadap macam-macam masalah, 4) lebih senang bekerja sendiri, 5) siswa mudah bosan dan tidak suka tugas berulang-ulang, 6) dapat mempertahankan pendapatnya, 7) senang mencari dan memecahkan masalah soal-soal. (Yuliati Kurnia Sari, 2013)

Hasil yang diemukan berdasarkan uraian hasil tindakan yang telah dilakukan pada siklus pertama diketahui, bahwa pada siklus 1 pertemuan 1 aktivitas guru dalam proses pembelajaran dengan menggunakan strategi hembusan angin kencang memperoleh skor 21, dengan pencapaian 2 indikator dilakukan guru dengan sangat baik, 3 indikator 
dilakukan guru dengan baik, dan 2 indikator dilakukan dengan "cukup baik", dengan persentase 75\%. Sedangkan pada siklus 1 pertemuan 2 aktivitas guru dalam proses pembelajaran dengan menggunakan strategi hembusan angin kencang memperoleh skor 23, dengan pencapaian 2 indikator dilakukan guru dengan sangat baik, 5 indikator dilakukan guru dengan baik. Aktivitas guru pada siklus 1 pertemuan 2 mengalami peningkatan dari sebelumnya, dimana persentase aktivitas guru menggunakan strategi hembusan angin kencang pada siklus 1 pertemuan 2 adalah 82,14\%.

Tabel 1. Rekapitulasi Aktivitas Guru

\begin{tabular}{|c|c|c|c|c|c|}
\hline \multirow{3}{*}{ No } & \multirow{3}{*}{ Aktivitas yang diamati } & \multicolumn{2}{|c|}{ Siklus 1} & \multicolumn{2}{|c|}{ Siklus 2} \\
\hline & & Ke 1 & Ke 2 & Ke 1 & Ke 2 \\
\hline & & Nilai & Nilai & Nilai & Nilai \\
\hline 1. & $\begin{array}{l}\text { Guru menjelaskan tujuan } \\
\text { pembelajaran }\end{array}$ & 3 & 3 & 4 & 4 \\
\hline 2. & $\begin{array}{l}\text { Guru menjelaskan prosedur } \\
\text { pelaksanaan strategi yang } \\
\text { digunakan }\end{array}$ & 4 & 4 & 4 & 4 \\
\hline 3. & $\begin{array}{l}\text { Guru meminta siswa } \\
\text { membentuk kursi menjadi } \\
\text { bentuk lingkaran dan duduk } \\
\text { pada kursi tersebut. }\end{array}$ & 3 & 3 & 4 & 4 \\
\hline 4. & $\begin{array}{l}\text { Guru meminta siswa pindah ke } \\
\text { kursi lain jika setuju dengan } \\
\text { pernyataan guru }\end{array}$ & 2 & 3 & 3 & 4 \\
\hline 5. & $\begin{array}{l}\text { Guru berdiri di tengah lingkaran } \\
\text { siswa dan mengucapkan } \\
\text { pernyataan, contoh “" }\end{array}$ & 4 & 4 & 4 & 4 \\
\hline 6. & $\begin{array}{l}\text { Guru dan siswa berlari menuju } \\
\text { kursi yang kosong }\end{array}$ & 2 & 3 & 3 & 4 \\
\hline 7. & $\begin{array}{l}\text { Siswa yang tidak mendapatkan } \\
\text { kursi berdiri di tengah lingkaran, } \\
\text { guru memberikan pertanyaan } \\
\text { kepada siswa yang berdiri di } \\
\text { tengah, kemudian proses } \\
\text { berlanjut seterusnya. }\end{array}$ & 3 & 3 & 3 & 3 \\
\hline \multicolumn{2}{|c|}{ Jumlah } & 21 & 23 & \multirow{2}{*}{$\begin{array}{l}25 \\
89,28 \%\end{array}$} & \multirow{2}{*}{$\begin{array}{l}27 \\
96,42 \%\end{array}$} \\
\hline \multicolumn{2}{|c|}{ Persentase } & $75 \%$ & $82,14 \%$ & & \\
\hline
\end{tabular}

Pada siklus 2 pertemuan 1 aktivitas guru menggunakan strategi hembusan angin kencang dengan pencapaian, 4 indikator dilakukan guru dengan sangat baik, 3 indikator dilakukan guru dengan baik. Kelemahan pada siklus pertama merupakan landasan untuk perbaikan pada siklus 1 . Aktivitas guru pada siklus 2 pertemuan 1 mengalami peningkatan dari sebelumnya, dimana persentase aktivitas guru menggunakan strategi hembusan angin kencang pada siklus 2 pertemuan 1 adalah 89,28\%. Pada siklus 2 pertemuan 1 aktivitas guru menggunakan strategi hembusan angin kencang dengan pencapaian 6 indikator dilakukan guru dengan sangat baik, 1 indikator dilakukan guru dengan baik. Aktivitas guru 
pada siklus 2 pertemuan 2 mengalami peningkatan dari sebelumnya, dimana persentase aktivitas guru menggunakan strategi hembusan angin kencang pada siklus 2 pertemuan 2 adalah $96 \%$. Dengan meningkatnya aktivitas yang dilakukan guru, maka aktivitas dan motivasi belajar siswa juga mengalami peningkatan. Untuk lebih jelasnya dapat dilihat dari tabel rekapitulasi aktivitas guru, rekapitulasi aktivitas belajar siswa, dan rekapitulasi motivasi belajar siswa berikut ini:

Grafik perbandingan aktivitas guru dalam penggunaan strategi hembusan angin kencang dapat dilihat sebagai berikut:

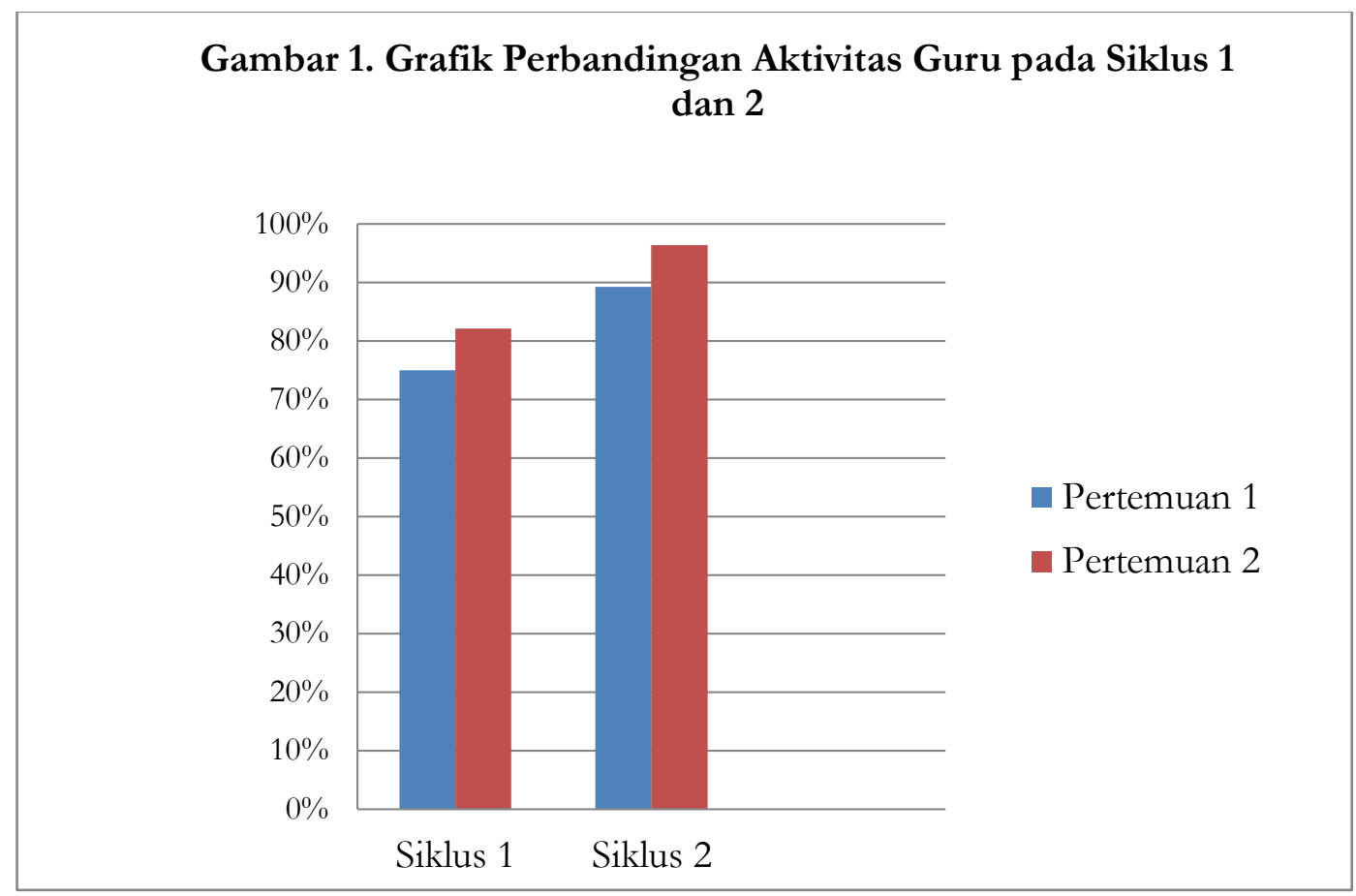

Berdasarkan grafik di atas terlihat bahwa pada setiap siklus, aktivitas guru mengalami peningkatan. Hal ini selaras dengan apa yang dikemukakan oleh Dimyati dan Mudjiyono bahwa semakin tinggi motivasi guru dalam mengajar akan berpengaruh pada aktivitas yang guru lakukan, artinya semakin tinggi motivasi, maka aktivitas guru juga akan lebih baik (Dimyati, Mujiono, 2009). Sementara rekapitulasi aktivitas siswa menggunakan strategi hembusan angin kencang dapat dilihat sebagai berikut:

\section{Tabel 2. Rekapitulasi Aktivitas Siswa Menggunakan Strategi Hembusan Angin Kencang}

\begin{tabular}{lllll}
\hline No & Siklus & Pertemuan & Presentase & Keterangan \\
\hline \multirow{2}{*}{1} & Siklus 1 & Pertemuan 1 & $68,89 \%$ & Cukup Baik \\
& & Pertemuan 2 & $74,43 \%$ & Cukup Baik \\
2 & \multirow{2}{*}{ Siklus 2 } & Pertemuan 1 & $81,76 \%$ & Baik \\
& & Pertemuan 2 & $87,87 \%$ & Baik \\
\hline
\end{tabular}

Adapun grafik perbandingan aktivitas siswa menggunakan strategi hembusan angin kencang dapat dilihat sebagai berikut: 


\section{Gambar 2. Grafik Perbandingan Aktivitas Siswa Menggunakan Strategi Hembusan Angin Kencang}



Dari grafik tersebut terlihat bahwa aktivitas siswa mengalami peningkatan dalam penggunaan strategi hembusan angin kencang. Guru merupakan ujung tombak dalam proses pembelajaran yang sangat mempengaruhi keberhasilan aktivitas belajar siswa karena guru berhadapan langsung dengan siswa hal tersebut sesuai dengan teori Dimyati dan Mudjiono. Jadi keberhasilan aktivitas siswa berkaitan dengan keberhasilan aktivitas guru. Dan rekapitulasi motivasi belajar siswa menggunakan strategi hembusan angin kencang dapat dilihat sebagai berikut:

\section{Tabel 3. Rekapitulasi Motivasi Belajar Siswa}

\begin{tabular}{lllll}
\hline No & Siklus & Pertemuan & Presentase & Keterangan \\
\hline 1 & Sebelum tindakan & - & $61 \%$ & Cukup baik \\
2 & Siklus 1 & Pertemuan 1 & $68 \%$ & Cukup baik \\
& & Pertemuan 2 & $72 \%$ & Cukup Baik \\
3 & Siklus 2 & Pertemuan 1 & $80,2 \%$ & Baik \\
& & Pertemuan 2 & $85,3 \%$ & Baik \\
\hline
\end{tabular}

Dan grafik motivasi belajar siswa menggunakan strategi hembusan angin kencang dapat dilihat sebagai berikut:

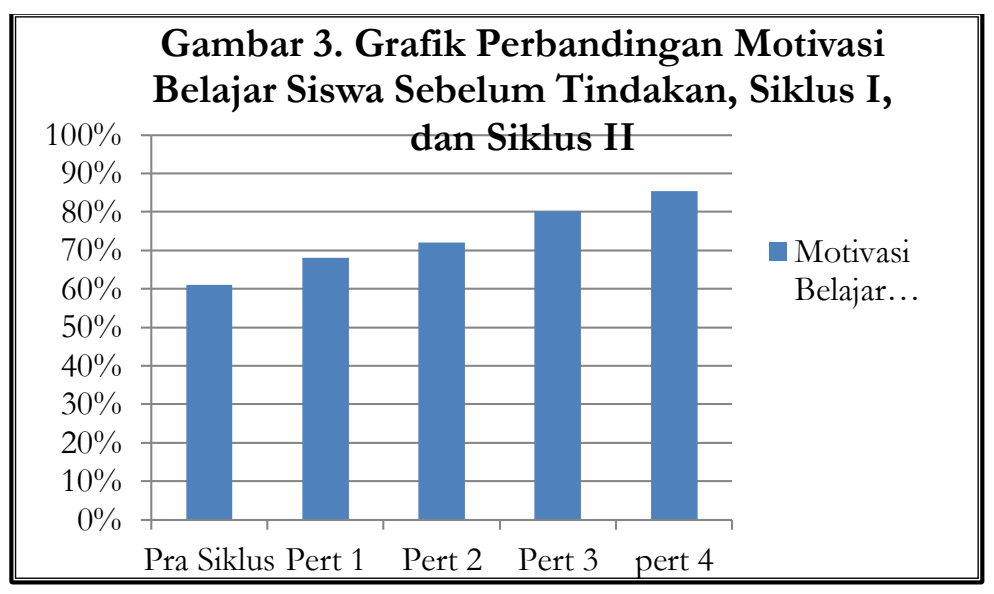


Dari grafik terlihat bahwa strategi hembusan angin kencang dapat meningkatkan motivasi belajar siswa sesuai dengan teori Melvin L.Siberman strategi hembusan angin kencang merupakan kegiatan yang memberi siswa keleluasaan untuk bergerak dan tertawa, serta dapat memecahkan kebekuan yang terjadi pada siswa selama proses pembelajaran. Kegiatan ini merupakan sarana pembentuk tim yang baik dan menjadikan siswa untuk lebih mengenal satu sama lain.

Sehingga ketika siswa belajar, siswa akan tertawa dan bebas bergerak sehingga pembelajaran pun menjadi menyenangkan dan memberi respon yang baik serta mengurangi kejenuhan selama proses belajar berlangsung sehingga motivasi belajar siswa pun akan meningkat.

\section{KESIMPULAN}

Berdasarkan pembahasan dan analisis data membuktikan bahwa strategi hembusan angin kencang dapat meningkatkan motivasi belajar siswa pada mata pelajaran ilmu pengetahuan sosial di kelas V Sekolah Dasar Negeri 20 Pekanbaru. Dengan penerapan strategi hembusan angin kencang dalam proses belajar mengajar membuat aktivitas belajar siswa menjadi lebih baik dan ini tentunya menunjang peningkatan motivasi belajar siswa. Dari hasil observasi, motivasi belajar siswa pada siklus 1 pertemuan 1 memperoleh skor 828 dengan persentase 68\% dan kategori cukup baik, sedangkan pada pertemuan 2 memperoleh skor 878 dengan persentase $72 \%$ dan kategori cukup baik, sedangkan hasil observasi motivasi belajar siswa pada siklus 2 pertemuan 1 memperoleh skor 975 dengan persentase 80,2 \% dan kategori baik, sedangkan pada pertemuan 2 memperoleh skor 1037 dengan persentase 85,3 dan kategori baik.

\section{REFERENSI}

Djamarah, S.B. (2011). Psikologi Belajar. Jakarta: Rineka Cipta.

Erni, S. (2011). Modul Pendalaman Materi IPS. Pekanbaru: Zanafa Publishing.

Kunandar. (2008). Langkah Mudah Penelitian Tindakan Kelas. Jakarta: Rajawali Pers.

Kurniawati, O. (2012). Penerapan Strategi The Great Wind Blows untuk Meningkatkan Hasil Belajar pada Mata Pelajaran Pkn Siswa Kelas IV SDN III Kopen Kecamatan Jatipurno Kabupaten Wonogiri. Surakarta: Universitas Muhammadiyah Surakarta.

Rizki, M. (2015). Penerapan Strategi The Great Wind Blows dalam Meningkatkan Hasil Belajar Siswa Kelas VII pada Mata Pelajaran Pendidikan Agama Islam di SMP Adabiyah Palembang. Palembang: Universitas Islam Negeri Raden Fatah Palembang.

Rosida, A. ( 2014). Penerapan Strategi The Great Wind Blows untuk Meningkatkan Hasil Belajar Siswa pada Mata Pelajaran Ilmu Pengetahuan Sosial Kelas V MI Muhammadiyah Simpang Kubu Kecamatan Kampar Kabupaten Kampar.

Saidiharjo dan Sumadi, HS. Konsep Dasar Ilmu Pengetahuan Sosial. Yogyakarta : FIP FKIP.

Sanjaya, W. (2006). Strategi Pembelajaran Berorientasi Standar Proses Pendidikan. Bandung : Kencana. 
Sanusi, A. (1971). Studi Sosial di Indonesia. Bandung : Ikip.

Sari, Y.K. (2013). Peningkatan Motivasi dan Hasil Belajar Siswa pada Pembelajaran IPA melalui Metode The Great Wind Blows di Kelas IV SDN 36 Kinali Kabupaten Pesaman Barat.

Siberman, M.L. (2009). Active Learning. Bandung: Remaja Nusamedia.

Sudjono, A. (2004). Pengantar Statistik Pendidikan. Jakarta : Raja Grafindo Persada.

Suprijono, A. (2009). Cooperative Learning. Yogyakarta: Pustaka Pelajar.

Uno, H.B. (2011). Teori Motivasi dan Pengukurannya. Jakarta: Bumi Aksara.

Wahidmurni. (2010). Pengembangan Kurikulum IPS dan Ekonomi di Sekolah/Madrasah. Malang: UIN Maliki Press.

Zalyana. (2014). Psikologi Pembelajaran. Pekanbaru: Mutiara Pesisir Sumatra. 